J-ABDIPAMAS (Jurnal Pengabdian Kepada Masyarakat)

Vol. $4 \bullet$ No. $2 \bullet 2020$

ISSN : 2581-1320 (Print) ISSN : 2581-2572 (Online)

Homepage: http://ejurnal.ikippgribojonegoro.ac.id/index.php/J-ABDIPAMAS

\title{
PENDAMPINGAN MAHASISWA TERHADAP METAMORFOSIS PEMBELAJARAN DIMASA PANDEMI COVID 19
}

\author{
Diana Kartika ${ }^{1}$, Oslan Amril², Ali Mardius ${ }^{3}$, Andika Prajana4, Yuni Astuti ${ }^{5}, Z^{4}$ lbahri ${ }^{6}$ \\ ${ }^{1}$ Universitas Bung Hatta Padang. Email: dianakartika@bunghatta.ac.id \\ 2Universitas Bung Hatta Padang. Email: barqawi1710@gmail.com \\ 3Universitas Bung Hatta Padang. Email: alimardius@bunghatta.ac.id \\ ${ }^{4}$ UIN Ar-Raniry Banda Aceh. Email: ndikaprajana@ar-raniry.ac.id \\ 5Universitas Negeri Padang. Email: yuniastuti@fik.unp.ac.id \\ 5Universitas Negeri Padang. Email: zulbahri@fik.unp.ac.id
}

\begin{abstract}
This community service program aims to provide assistance to college students in learning process that changes due to the impact of the Covid-19 Pandemic. There has been a change in learning that was initially offline or carried out at the campus but because of the pandemic it was directed into online learning of course has weaknesses and shortcomings. The continuity of this program is to understand and prepare for online learning both in terms of IT, immunity, ethics and others in the future so that learning outcomes can still be achieved even though the process is online
\end{abstract}

Keywords: Speaking Ethics, Mastery of IT, enhancing body immunity

\begin{abstract}
ABSTRAK
Kegiatan pengabdian kepada masyarakat ini bertujuan untuk memberikan pendampingan kepada mahasiswa dalam proses pembelajaran yang berubah karena dampak Pandemi Covid 19. Terjadinya perubahan pembelajaran yang awalnya luring atau dilakasanakan di kampus tetapi karena pandemi maka di arahkan pada daring yang tentunya memiliki kelemahan dan kekurangan. Keberlanjutan dari program ini adalah agar mamahami dan mempersiapkan diri untuk pembelajaran daring baik dari segi IT, imun tubuh, etika dan lainnya pada masa berikutnya sehingga capaian pembelajaran tetap tercapai walaupun prosenya daring.
\end{abstract}

Kata Kunci: Etika Berbicara, Penguasaan IT, peningkatan imun Tubuh

\section{PENDAHULUAN}

Perubahan pelaksanaan pembelajaran dari luring menjadi daring karena wabah pandemi covid 19 menyebabkan terjadinya metamorfosis pembelajaran pada seluruh Perguruan Tinggi. Definisi metamorfosis menurut kbbi.web id/metamorfosa adalah perubahan bentuk. Kalau dikaikan dengan metamorfosis pembelajaran pada masa pandemi maka perubahannya sangat sinifikan karna biasanya pembelajaran dilakukan dikampus dengan luring atau tatap muka langsung di kelas sekarang dilakukan didalam jaringan. Nurhayati (2020) Perubahan yang begitu pesat terjadi di dunia pendidikan sehingga metode pendikan yang konvensional dirasa menjadi kurang efektif karena masalah ruang dan waktu sehingga metode pendidikan menawarkan metode yang 
dinamakan elearning. Selanjutnya Ramadhan (2018) mengungkapkan bahwa teknologi informasi dan komunikasi dalam bidang pembelajaran merupakan sarana prasarana pendukung seseorang atau sekelompok orang maupun organisasi dalam memperoleh pengalaman belajar yang lebih baik. Sedangkan Prajana (2020) berpendapat bahwa efisensi interaksi setiap manusia akan terwujud apabila pemanfaatan teknologi informasi memiliki impact terhadap kuantitas dan kualitas terhadap pemanfaatan teknologi tersebut. Khusniyah (2019) mengatakan bahwa seorang pendidik harus memiliki 4 kompetensi agar dapat menggunakan teknologi secara tepat guna, kompetensi tersebut yaitu harus mampu menggunakan teknologi, memiliki kemampuan meangarahkan peserta didik dalam penggunaan teknologi, memprediksi perubahan dengan cepat, dan kompetensi mengendalikan diri.

Kondisi ini mengakibatkan banyak permasalahan terutama mahasiswa alam melakasanakan proses belajar mengajar. Dari sekian banyak perubahan yang terjadi dalam pembelajaran faktor etika dalam berbahasa, kemampuan teknologi informasi dan daya tahan tubuh yang telihat jelas dalam perkuliahan daring. Salah satu contoh dalam daya tahan tubuh atau kondisi fisik, faktor yang sangat mendukung dalam usaha pencapaian proses pembelajaran dan memtus mata rantai pandemi. Zulbahri (2019) mengatakan bahwa untuk melakukan aktivitas agar tumbuh dan berkembang dengan baik maka setiap insan harus memiliki kondisi fisik yang bagus. Menurut Jonath dan Krempel dalam Syafruddin (2011:91) kondisi fisik dibedakan atas pengertian sempit dan luas. Dalam arti sempit kondisi fisik merupakan keadaan yang meliputi kekuatan (strength), kecepatan (speed), dan daya tahan (endurance). sedangkan dalam arti luas meliputi ketiga unsur tersebut dan ditambah dengan unsur kelentukan (flexibility), dan koordinasi (coordination).

Erianti dan Pitnawati (2018) menjelaskan bahwa daya tahan merupakan keadaan atau kondisi tubuh seseorang yang mampu untuk melakukan akktivitas tanpa mengalamai kelelahan yang berlebihan serta masih memiliki tenaga cadangan untuk melakukan aktivitas berikutnya Seseorang dikatakan mempunyai daya tahan yang baik apabila ia tidak mudah lelah atau dapat terus bergerak dalam keadaan diambang kelelahan, atau ia mampu bekerja tanpa mengalami kelelahan yang berlebihan setelah menyelesaikan pekeraan tersebut. Dengan demikian daya tahan cardiovascular berkaitan dengan daya tahan jantung paru sangat menentukan kemampuan seorang atlet dalam melakukan aktivitas dengan durasi yang lama, serta dapat mengatasi kelelahan pada saat mengikuti latihan secara terus menerus dalam waktu yang lama dalam setiap penampilan, baik dalam melakukan pelatihan maupun pertandingan. didalam cabang pencak silat, seorang atlet harus memiliki kemampuan untuk mencapai detak jantung maksimal atau kemampuan untuk meningkatkan stroke volume agar dapat menampilkan gerakan secara optimal tanpa merasakan kelelahan yang berarti.

Pelaksanaan pengabdian pada masyarakat yang dilakukan merupakan bentuk pendampingan dalam pembelajaran daring, perubahan yang terjadi pada saat pembelajaran daring dilaksanakan, bagaimana kiat-kiat mengantisipasi dan mengoptimalkan agar proses pembelajaran tetap berjalan sesuai dengan capaian pembelajaran yang sudah ditetapkan. Pada program ini masyarakat mitra yang dijadikan 
adalah mahasiswa yang tersebar pada tiga perguruan tinggi Bung Hatta, Universitas Negeri Padang UIN Ar-Raniry dan mahasiswa universitan lain sebanyak lebih kurang 150 mahasiswa

Persoalan yang prinsip yang terjadi pada pelakasanaan pembelajaran daring pada masa pandemi covid 19 adalah perubahan dari metoda pembelajaran dimana semua bahan pembelajaran harus disampaikan dalam jaringan ini mengkibatkan ketidak siapan mahasiswa dalam menangapi cepat suasana yang mau tidak mau harus dilakukan padahal mahasiswa sudah terbiasa diberikan secara langsung di kampus kondisi ini diperparah lagi dengan sistem daring yang sangat ditentukan jaringan dan spec Hp yang dimiliki yang terkadang tidak mampu mendowload aplikasi belajar daring itu sendiri seperti zoom, meet, cloud X dan lain-lain.

Pola belajar mahasiswa yang biasa tatap muka langsung dan sekarang beralih pada daring juga mengakibatkan terganngunya psikis dan dampak daya tahan tubuh berkurang karna hanya menoton dirumah saja, sehingga tidak dipungkiri kalau emosi cepat naik sehingga tutur bahasa tidak bagus lagi, terkadang dalam perkuliah on line ada yang tidak sabar dan keluar masuk dalam aplikasi secara langsung serta dapat menampilkan prilku cara berbicara dan bersikap yang tidak sesuai dengan seharusnya. Dengan menurunnya kondisi fisik selama masa pandemi karna tidak beleh keluar rumahkebanyakan mahasiswa tidak beremangat dalam perkuliahan daring dan ini dikwatirkan pembelajaran tidak sesuai dengan harapan atau tujuan yang diinginkan.

Tujuan dari pelaksanaan program webinar ini adalah agar mahasiswa mampu melaksanakan pembelajaran dengan baik dan mencari solusi yang cepat agar kendalakendala yang mungkin terjadi pada saat pembelajaran terjadi, menampilkan tata tutur kata yang sopan walaupun didalam jaringan karna akan live langsung walaupun tidak bertatap muka seperti pembelajaran dilokal tentu adat atau norma walaupun di aplikasi tetap dijalankan sesuai dengan aturan agar mahasiswa tetap memiliki akhlak dan etika walaupun pembelajarannya dilakukan dengan aplikasi daring. Pentingnya penggunanan bahasa yang baik dan santun perlu diperhatikan dengan baik oleh pengguna baik dari segi pendidik maupun peserta didik, karena bahasa merupakan alat yang digunakan untuk berkomunikasi (Kartika, 2017). Selanjutnya pentingnya menjaga atau penguatan kondisi fisik untuk mendukung pelaksanaan pembelajaran pada masa pandemic covid juga menjadi salah satu alternatif yang bisa dilakukan, karna disamping menambah motivasi dalam pembelajaran dalam meningkatkan konsentrasi, kondisi fisik yang baik juga dapat menangkal masuknya virus yang sekarang sedang mewabah artinya dapat memutus mata rantai penyebaran covid 19.

\section{METODE PELAKSANAAN}

Pelaksanaan program ini dilakukan dengan cara mengadakan webinar melalui aplikasi geogle Meet, dilakukan dengan cara pemaparan materi oleh narasumber. Dimana langkah-langkah yang dilakukan sebagai berikut:

1. Persiapan pada kegiatan ini dilakukan penentuan jadwal, materi yang akan disampaikan, sesuai dengan topik oleh masing-masing nara sumberpendaftaran peserta melauli google form. 
2. Pelaksanaan Webinar pada waktu yang telah ditentukan dengan para nara sumber lintas perguruang tinggi dengan topik yang sudah disepakati yang dilakukan oleh tim dosen pelaksana program pengabdian kepada masyarakat.

3. Monitoring selanjutnya diskusi dilakukan untuk melihat dan mendengar kesan dan keluhan mahasiswa dalam pelaksanaan pembejaran daring dan metamorfosis yang terjadi. Sehingga diharapkan hasil yang dicapai dalam program ini akan lebih baik.

Pelaksanaan PKM ini disesuaikan dengan tema yang diusung berkaitan dengan pembelajaran di masa pandemic Covid19. Pada pelaksanaan kegiatan secara bergantian penyampaian materi dari masing-masing nara sumber.

1. Materi Informasi dan Teknologi (IT) secara daring disampaikan oleh Andika Prajana, M.Kom. dari Program Studi Teknologi Informasi UIN Ar-Raniry Banda Aceh. Dalam pemaparannya disampaikan bahwa pembelajaran pada masa pandemic Covid 19 setidaknya perlu kesiapan sarana pembelajaran berupa perangkat yang bisa terhubung secara daring serta kompetensi dari mahasiswa dalam menggunakan perangkat. Media juga diperlukan dalam pembelajaran dengan tujuan untuk merangsang pikiran, perhatian dan kemauan peserta didik sehingga terjadiny proses pembelajaran (Nuris, dkk, 2020)

2. Materi Etika Komunikasi Dunia Maya, dan Kesantunan Berbahasa Dunia Maya secara bergantian disampaikan oleh Prof. Dr. Diana Kartika dan Oslan Amril, S.S., M.Si. dan dari Universitas Bung Hatta. Di masa pandemi pembelajaran yang dilaksanakan secara daring haruslah juga memperhatikan kaidah-kaidah etika komunikasi dan kesantunan berbahasa dalam pelaksanaannya. Walaupun kita tidak betatap muka secara langsung dengan lawan bicara seyogyanya etika dan kesantunan berbahasa merupakan hal yang harus diperhatikan sebagai mahluk sosial.

3. Materi Menjaga Kesehatan Tubuh Melalui Olahraga di Masa Pandemi disampaikan oleh Ali Mardius, S.Pd., M.Pd., dari Universitas Bung Hatta dan Zulbahri, S.Pd., M.Pd. dan Yuni Astuti, S.Pd, M.Pd dari Universitas Negeri Padang. Menjaga stamina di tengah pandemi dengan melakukan olahraga ringan setidaknya dapat mendukung pelaksanaan pembelajaran pada masa pandemic covid juga menjadi salah satu alternatif yang bisa dilakukan, karna disamping menambah motivasi dalam pembelajaran dalam meningkatkan konsentrasi, kondisi fisik yang baik juga dapat menangkal masuknya virus yang sekarang sedang mewabah artinya dapat memutus mata rantai penyebaran covid 19. Di akhir kegiatan peserta yang berasal dari berbagai perguruan tinggi di pulau Sumatera diberi kesempatan untuk diskusi dengan nara sumber sesuai dengan bidang masing- masing. Antusias peserta terlihat dari jumlah peserta yang mendaftar secara online sampai jadwal pelaksanaan kegiatan.

\section{HASIL DAN PEMBAHASAN}

Berdasarkan hasil analisis data yang diperoleh dari data angket yang diberikan kepada peserta dengan kisi-kisi angket tentang pengetahuan teknologi informasi, etika dunia maya serta kesantunan berbahasa, kesehatan dan olahraga dapat dilihat lebih jelas dari deskripsi data berikut. 


\section{Pengetahuan TIK}

Dari 131 responden kegiatan webinar sebagian besar $(55,7 \%)$ sudah memiliki sarana TIK untuk membantu dalam perkuliahan online pada masa pandemi dan merasa belajar online di rumah lebih efektif, walaupun tetap menginginkan dan lebih suka kuliah secara konvensional (tatap muka). Terkait jaringan internet responden sudah sangat siap dengan fasilitas jaringan yang dimiliki. Responden memberikan respon negatif dengan metode perkuliahan yang dilakukan dosen yang kurang membantu mereka dalam memahami materi perkuliahan. Penyampaian materi perkuliahan online yang tidak maksimal mengakibatkan tugas yang diberikan dosen menambah beban bagi mahasiswa. Berhubungan dengan penggunaan media pembelajaran online responden menilai bahwa media youtube masih lebih baik dibandingkan dengan aplikasi lain yang sejenis.

\section{Etika Dunia Maya Dan Kesantunan Berbahasa}

Lebih dari 72\% dari 131 responden sudah menerapkan etika dan meyakini bahwa etika dan kesantunan mutlak dan menilai kesantunan berbahasa dalam komunikasi di dunia maya yang dapat mencerminkan pribadi seseorang. Sebagian besar responden sudah melakukan klarifikasi terhadap suatu informasi sebelum membagikan ke orang lain. Responden menyadari bagaimana seharusnya memanfaatkan teknologi informasi secara aman, tidak menimbulkan kerugian diri sendiri maupun orang lain. Hal negatif dari responden $(55,7 \%)$ adalah pendapat bahwa tidak harus mencantumkan identitas pribadi dengan jelas untuk menghindari tuntutan hukum dalam pelanggaran berkomunikasi di dunia maya. Hal ini jelas bertentangan dengan Undang-undang ITE. Masih ada sebagian responden (46.6\%) beranggapan bahwa dengan membuat status di media sosial dunia maya dapat melepaskan diri dari permasalahan yang dihadapi.

\section{Kesehatan Dan Olahraga}

Di bidang kesehatan dan olahraga pada masa pandemi Covid-19 responden sangat setuju $(55,7 \%)$ bahwa melaksanakan olahraga secara teratur dan kontiniu serta istirahat yang cukup, dan menjaga pola makan bergizi perlu diperhatikan untuk menjaga imunitas tubuh. Responden juga menyadari $(61,1 \%)$ bahwa merokok termasuk tindakan yang merugikan karena dapat menurunkan tingkat kondisi fisik seseorang.

\section{SIMPULAN}

Era Revolusi Industri 4.0, dunia pendidikan tinggi menghadapi tantangan dengan berbagai perubahan yang ada. Ditambah adanya pandemi Covid-19 menuntut pendidikan tinggi untuk bisa melakukan penyesuaian dalam penyelenggaraan pendidikan. Salah satunya mengubah metode pembelajaran tatap muka (luring) menjadi daring saat pandemi. Tantangan besar dalam pelaksanaan model pembelajaran daring salah satunya adalah, sivitas akademika belum terbiasa menggunakan sistem pembelajaran yang bersifat blended dan sepenuhnya online. Muncul kesulitan karena belum dilatih mengunakan peralatan untuk model pembelajaran daring. Karenanya perlu tambahan dukungan dan mentoring untuk menyesuaikan dengan model pembelajaran baru ini Proses perkuliahan secara daring dinilai sebagai tantangan baru di dalam era revolusi 
industri Di saat seperti sekarang ini model pembelajaran berbasis digital telah dimaksimalkan secara masif hampir diseluruh Indonesia. Meskipun juga model ini terbilang belum secara menyeluruh menjangkau lapisan sosial bawah yang ada di masyarakat. Karena pada dasarnya model pembelajaran ini juga mempunyai syarat yang harus di penuhi yakni akses terhadap informasi digital. Untuk itu jika ditinjau dari akses terhadap teknologi digital, tidak semua mahasiswa mempunyai akses yang sama.

Untuk menghadapi metamorphosis pembelajaran secara daring kesiapan perangkat dan jaringan inretnet merupakan sebuah keharusan. Di samping itu sebagai mahluk sosial mahasiswa harus tetap menjaga etika komunikasi dan keantuanan berbahasa walau tidak bertatap muka langsung dengan lawan bicara. Dan yang tidak kalah pentingnya adalah tetap menjaga kesehatan untuk tidak tertular Covid 19 dengan menjaga pola pola makan, pola hidup bersih dan melakukan olahraga ringan dengan protokol Covid yang disarankan.

\section{UCAPAN TERIMA KASIH}

Terimakasih kami ucapkan kepada mahasiswa dari Universitas Islam Negeri ArRaniry Banda Aceh, Universitas Islam Negeri Sumatera Utara, Universitas Samudra Langsa Aceh, Universitas Pasir Pangarayan, Universitas Bung Hatta dan Universitas Negeri Padang yang telah bersedia meluangkan waktunya untuk mengikuti acara seminar online atau Webinar dalam mengahadapi pembelajaran pada masa pandemic covid 19.

\section{DAFTAR RUJUKAN}

Erianti dan Pitnawati. 2018. Pembinaan Senam Aerobik dalam Upaya Meningkatkan Kebugaran Jasmani Masyarakat Pondok Pinang Lubuk Buaya Kecamatan Koto Tangah Kota Padang. International Journal of Community Service Learning. Volume 2, Number 4.

Kartika Diana. Dkk. 2017. Pengenalan Bahasa dan Budaya Jepang Bagi Guru dan Siswa. Jurnal Pengabdian dan Pemberdayaan Masyarakat. Volume 1 No 2.

Khusniyah Nurul Lailatul \& Hakim Lukam. 2019. Efektifitas Pembelajaran Berbasis Daring: Sebuah Bukti Pada Pembelajaran Bahasa Inggris. Jurnal Tatsqif: Jurnal Pemikiran dan Penelitian Pendidikan. Vol 17 No 1.

Nurhayati. 2020. Metode Pembelajaran Daring/E-Learning Yang Efektif. Research Gate.

Nuris Dudung Ma'aruf, Nagari Primasa Minerva, Nuraini Umi (2020). Pelatihan Pembuatan Bahan Ajar dan Media Pembelajaran Berbasis TIK Bagi Guru Akuntasi. J-Abdipamas (Jurnal Pengabdian Kepada Masyarakat) Vol 4 No 1.

Prajana Andika \& Astuti Yuni. 2020. Pemanfaatan Teknologi Informasi dan Komunikasi dalam Pembelajaran Oleh Guru SMK di Banda Aceh dalam Upaya Implementasi Kurikulum 2013. Jurnal Inovasi Teknologi Pembelajaran. Vol 7 (1).

Ramadhan Rizky. Dkk. 2018. Pengembangan Pembelajaran Bauran (Blended Learning) di Universitas Negeri Jakarta. Jurnal Pembelajaran Inovatif. Vol 1 No 1.

Syafruddin.2011. Ilmu Melatih Dasar. Padang: Sukabina Press. 
Zulbahri. 2019. Tingkat Kemampuan Daya Tahan Jantung dan Pernafasan Mahasiswa Pendidikan Olahraga dan Kesehatan Universitas Pasir Pengaraian. Jurnal Pendidikan Jasmani dan Olahraga. Vol 3 Nomor 1. 
8 J-Abdipamas, Vol. 4, No. 2 Oktober, 2020 